\title{
Nanostructural and geochemical features of the Jurassic isocrinid columnal ossicles
}

Jarosław Stolarski, Przemysław Gorzelak, Maciej Mazur, Yves Marrocchi, and Anders Meibom Acta Palaeontologica Polonica 54 (1), 2009: 69-75 doi:http://dx.doi.org/10.4202/app.2009.0108

Calcite isocrinid ossicles from the Middle Jurassic (Bathonian) clays in Gnaszyn (central Poland) show perfectly preserved micro- and nanostructural details typical of diagenetically unaltered echinoderm skeleton. Stereom pores are filled with ferroan calcite cements that sealed off the skeleton from diagenetic fluids and prevented structural and geochemical alteration. In contrast with high-Mg calcite skeleton of modern, tropical echinoderms, the fossil crinoid ossicles from Gnaszyn contain only 5.0-5.3 mole\% of $\mathrm{MgCO}$. This low $\mathrm{Mg}$ content can be a result of either a low temperature environ- ment $\left(\mathrm{ca} .10^{\circ} \mathrm{C}\right.$ ) and/or low $\mathrm{Mg} / \mathrm{Ca}$ seawater ratio. Both conditions have been proposed for the Middle Jurassic marine environment. Occurrence of $\mathrm{Mg}$-enriched central region of stereom bars of Jurassic columnal ossicle of Chariocrinus andreae is consistent with the concept of magnesium ions involvement in earliest growth phases of calcium carbonate biominerals.

Key words: Echinodermata, Crinoidea, calcite, nanostructure, geochemistry, AFM, NanoSIMS, Jurassic

Jarosław Stolarski [stolacy@twarda.pan.pl], and Przemysław

Gorzelak [przemyslaw.gorzelak@gmail.com], Institute of Paleobiology,

Polish Academy of Sciences, ul. Twarda 51/55, PL-00-818 Warsaw, Poland;

Maciej Mazur [mmazur@chem.uw.edu.pl], Department of Chemistry, Laboratory of Electrochemistry, University of Warsaw, ul. Pasteura 1, PL-02-093 Warsaw, Poland; Yves Marrocchi [marrocchi@mnhn.fr] and Anders Meibom [meibom@mnhn.fr], Muséum National d'Histoire Naturelle, Laboratoire d'Etude de la Matiere Extraterrestre, USM 0205 (LEME), Case Postale 52, 61 rue Buffon, 75005 Paris, France.

This is an open-access article distributed under the terms of the Creative Commons Attribution License (for details please see creativecommons.org), which permits unrestricted use, distribution, and reproduction in any medium, provided the original author and source are credited. 
PoF Full text (652.7 kB) 